\title{
A Survey of Passiflora foetida L. and Associated Weed Species on Arable Crops in Ballah, Southern Guinea Savanna Zone Of Nigeria.
}

\author{
*Takim, F.O., Olaoye, A.O.and Adeyemo, J. \\ Department of Agronomy, Faculty of Agriculture, \\ University of Ilorin, P.M.B. 1515, Ilorin, Nigeria \\ *Corresponding Author : felixtakim@yahoo.co.uk
}

\begin{abstract}
Asurvey was conducted in the research field of the Institute ofAgricultural Research and Training, Obafemi Awolowo University Ile-Ife, Ballah sub-station in southern Guinea savanna of Nigeria during 2010 to 2011 cropping season with an objective to determine the relative abundance of Passiflora foetida $L$. and predict the potential of the weed species dominating arable fields. Passiflora foetida $L$. was found to be with a high percentage frequency of occurrence (16.99\%) and relative abundance ranging from 27.05 to $62.29 \%$ at crop vegetative stage and 17.49 to $74.75 \%$ during harvesting of arable crops. The fields of cowpea and soyabean had higher frequencies of occurrence of the alien weed compare with sole cassava and maize plots and their intercrops with lower frequencies of occurrence. This study advocated periodic observation of weed flora by farmers to ascertain cases of invasion of farmlands by alien weed species to facilitate early management strategy that could limit spread of such weed species.
\end{abstract}

Keywords : Passiflora foetida, arable crop fields, associated weed species, Ballah.

\section{INTRODUCTION}

Arable crop production in West Africa sub-region is experiencing an enormous economic losses due to crop pests. Weed is the number one pest which farmers must contend with in most common crops in West African agriculture. Weeds unlike other pests are ubiquitous and account for at least one third of this loss (Gurbachan, 2005). They cause enormous losses and sufferings to farmers by way of reduction in crop yield and quality, wastage of human energy and resources and increases cost of cultivation (Murugan \& Kathiresan, 2010).

In recent times, cases of invasion of farmlands by exotic plant species have been reported (Wilcove et al., 1998; Mack et al.,2000) causing negative impact on human health, the economy, native species and ecosystem (Pimentel et al., 2005). The rate of exotic species introduction appears to be increasing with globalization (Stohlgreen et al.,2008).

Passiflora comes from Latin word "Passio" that was first discovered by Spanish discoverers in 1529 and was described as a symbol for "Passion of Christ" (Kinghorn, 2001; Dhawan et al., 2004). The genus Passiflora, comprising about 400 species, is the largest in the family 
Passifloraceae (Montanher et al., 2007). A large genus of herbaceous or woody tendril climber (The Wealth of India, 2001), mostly distributed in the warm temperate and tropical regions of the World, but they are much rarer in Asia, Australia, and tropical Africa (Beninca et al., 2007). Many of the species are of ornamental value and a few are cultivated for their edible fruits.

Passiflora foetida (stinking passion flower) is a perennial herbaceous evergreen broadleaf herb of the family Passifloraceae. The whole plant has an unpleasant odour, but the ripe fruit is edible (Randall, 2003). It is commonly found as an invader on disturbed site and it favours wet areas (PIER, 2002), but can tolerate arid conditions (Randall, 2003). The weed is regarded as a native of South America but is now a pantropic weed which has also been introduced to tropical regions around the world. The fruit is edible, but not a common food item because it contains little pulp. It has a sweet taste, similar to the large fruited passion floras that are popular in other areas of the pacific (Moore and McMakin, 2002).

Passiflora foetida is a weed of upland rice and other field crops. It occurs in wet areas or those where there is a pronounced wet season. It is common in plantations, rough pastures, roadsides and wasteland (Mack et al.,2000). This weed is one of the most serious weed found in the forest savannah transition zone of sub-Saharan Africa and also in the high rainfall areas of southeast Asia.

In West Africa, it devastates field crop like rice, cotton field or grain legumes and plantation. Passiflora foetida infestation causes severe crop yield losses, land abandonment, deforestation and land degradation. In Nigeria, the weed is found in most part of the southern Guinea and Sudan savanna zone of the country where it forms a dense ground cover which prevent growth and development and delay the establishment of other species, especially the field crop like rice/cotton field also in grain legumes field and fallows (PIER, 2002).

A woody, annual or perennial vine, 1.5 to $6 \mathrm{~m}$ long; stem, cylindrical, densely hairy; tendrils arise next to leaves on the shaded side of the stem; leaves heart-shaped to three lobed, alternate, arranged helically, with long-stalked glands and long fine hairs on margins, producing a disagreeable smell when crushed; flowers white to lilac, bisexual. It flowers all year round, opening in the morning and closing before noon. The green to orange or red fruits are enclosed in lacy bracts. Alarge number of varieties occur (The wealth of India, 2001).

Traditionally the fresh or dried whole plant of $P$. foetida and their preparations are accepted for medicinal use in European countries for the treatment of nervous anxiety. It shows antispasmodic sedative, anxiolytic and hypotentive activities (Dhawan et al, 2001). The decoction from the leaves and fruits of this plant is used to treat asthma and hysteria. The leaf paste of $P$. foetida is applied for headache and to treat skin diseases (Chopra et al, 1956).

This weed species invaded the research field of the Institute of Agricultural Research and Training, Obafemi Awolowo University lle-Ife, Ballah sub-station in southern Guinea savanna of Nigeria. 
Peasant farmers around the research field believed that, the new weed was first seen few seasons after the departure of Fulani herdsmen that once settled in some portion of the research field. Therefore, managing this new weed species becomes necessary to prevent spread so as to increase crops production. Hence, this study of weeds in arable crops was carried out to determine the relative abundance of Passiflora foetida $L$. to see the urgent need for its management.

\section{Arable field survey}

\section{MATERIALS AND METHODS}

The southern Guinea savanna zone of Nigeria is one of the sub-zones of moist savanna zone of West and Central Africa, characterized by bimodal rainfall that varies from $1200-1500 \mathrm{~mm}$ and an average temperature range of $19^{\circ}-33^{\circ} \mathrm{C}$ and a length of growing period of about $181-270$ days.

The survey was conducted in research field of about 34 hectares at Ballah $\left(9^{\circ} 29^{\prime} \mathrm{N}, 4^{0} 35^{\prime} \mathrm{E}\right)$ of Nigeria and is $307 \mathrm{~m}$ above sea level during 2010-2011 growing season. Eight cropping systems were identified at the time of survey: sole cropping of cassava, maize, soyabean and cowpea, intercropping of cassava and maize, cassava and yam, cassava, maize and yam, and a fallow field.

The field survey was carried out according to the quantitative survey method described by Thomas (1985) and Kamal-Uddin et.al., (2009). Thirty-two transect lines were set to cover the research field and quadrats of size $1 \mathrm{~m} \times 1 \mathrm{~m}$ were arranged $20 \mathrm{~m}$ apart in a grid pattern across each transect line. Each transect line (had 16 - 21 quadrats depending on the length) was surveyed and observations were recorded from the quadrats. The weeds were identified using the hand book of West African Weeds (Akobundu and Agyakwa, 1998). Care was taken while selecting the fields to see that the crops were raised with normal care without any interference with weed control measure adopted until the completion of the survey. Data collected were density of Passiflora foetida $L$ and associated weeds during vegetative stage and at harvest of arable crops. The composition of the weed flora was analysed by calculating the relative abundance (RA) of each specie within each experimental unit as follows: $R A=(R D+R F) / 2$, where RD (relative density) = number of a weed specie per unit area (within a quadrat) in the plot divided by the total number of weed species within the same unit area (quadrat); and RF (relative frequency) = proportion of quadrat in which the species were present per experimental unit divided by the total frequency of all species in the experimental unit (Takim \& Fadayomi, 2009)

\section{RESULTS AND DISCUSSION}

Forty-three weed species, comprising twenty-nine broadleaves, eight grasses and six sedge weed species, were reported from arable fields of IAR \& T, Ballah sub-station during 2010 cropping season. Their frequency and percentage occurrence, were recorded (Table 1). 
Table 1. Frequency Occurrence of Weed Species Encountered Across Arable Fields

\begin{tabular}{|c|c|c|c|c|}
\hline \multirow[b]{2}{*}{ Weed species } & \multicolumn{2}{|c|}{ Frequency } & \multirow[b]{2}{*}{ Mean } & \multirow{2}{*}{$\begin{array}{l}\text { Relative } \\
\text { Frequency } \\
\%\end{array}$} \\
\hline & Vegetative & Harvest & & \\
\hline \multicolumn{5}{|l|}{ Broadleaves } \\
\hline Gomphrena celosioides Mart. & 28 & 33 & 44.5 & 1.26 \\
\hline Pupalia lappacea (Linn.) Juss. & 16 & 11 & 13.5 & 0.57 \\
\hline Amaranthus spinosus Linn. & 8 & 20 & 14 & 0.58 \\
\hline Celosia isertii C.C.Townsend & 23 & 20 & 21.5 & 0.90 \\
\hline Vernonia cinera (Linn.) Less. & 34 & 95 & 64.5 & 2.60 \\
\hline Synedrella nodiflora Gaertn. & 8 & 6 & 7 & 0.29 \\
\hline Chromolaena odorata (Linn.) R. M. King \& Robinson & 27 & 39 & 33 & 1.35 \\
\hline \multicolumn{5}{|l|}{ Vernonia ambigua Kotschy \& Peyr } \\
\hline Tridax procumbens (Linn.) & 287 & 303 & 295 & 12.20 \\
\hline Azolla Africana Desv. & 48 & 53 & 50.5 & 2.09 \\
\hline Daniellia oliveri(Rolfe) Hutch \& Dalz & - & 12 & 12 & 0.46 \\
\hline Combretum zenkeri Engl. \& Deils & 13 & 18 & 15.5 & 0.64 \\
\hline Aneilema beniniense (P. Beauv.) & 120 & 176 & 148 & 6.06 \\
\hline Commelina benghalensis Linn. & 59 & 63 & 61 & 2.53 \\
\hline Commelina diffusaBurm. & 22 & 24 & 23 & 0.97 \\
\hline Ipomoea eriopcarpa R. Br. & 59 & 61 & 60 & 2.49 \\
\hline Ipomoea triloba Linn. & 32 & 38 & 35 & 1.44 \\
\hline Phyllanthus amarus Schum. \& Thonn. & 16 & 18 & 17 & 0.71 \\
\hline Euphorbia heterophylla Linn. & 151 & 188 & 169.5 & 6.99 \\
\hline Alchornea cordifolia(Schum \& Thonn.) MullArg & 5 & 11 & 8 & 0.33 \\
\hline Acalypha ciliata Forsk. & 48 & 56 & 52 & 2.15 \\
\hline Crotalaria retusaLinn. & 11 & 7 & 9 & 0.40 \\
\hline Tephrosia bracteolata Guill. \& Perr. & 18 & 25 & 21.5 & 0.89 \\
\hline Schrankia leptocarpa DC. & 24 & 19 & 21.5 & 0.91 \\
\hline Mimosa pudica Linn. & 2 & 6 & 4 & 0.16 \\
\hline${ }^{\star}$ Passiflora foetida Linn. & 376 & 499 & 437.5 & 16.99 \\
\hline Mitracarpus villosus (Sw.) DC. & 30 & 36 & 33 & 1.36 \\
\hline Fleurya ovalifolia (Schum. \& Thonn.) Dandy & 38 & 24 & 31 & 1.31 \\
\hline Fleurya aestuans (Linn.) ex Miq. & 10 & 7 & 8.5 & 0.36 \\
\hline \multicolumn{5}{|l|}{ Sedges } \\
\hline Rhynchospora corymbosa (Linn.) Britt. & 4 & 15 & 9.5 & 0.39 \\
\hline Cyperus haspan Linn. & 42 & 51 & 46.5 & 1.94 \\
\hline Cyperus rotundus Linn. & 8 & 6 & 7 & 0.29 \\
\hline Mariscus alternifolius Vahl. & 3 & 8 & 5.5 & 0.22 \\
\hline Cyperus difformis Linn. & 14 & 19 & 16.5 & 0.68 \\
\hline Cyperus iria Linn. & 12 & 11 & 11.5 & 0.48 \\
\hline \multicolumn{5}{|l|}{ Grasses } \\
\hline Imperata cylindrica (Linn.) Raeuschel & 296 & 257 & 276.5 & 11.51 \\
\hline Rhynchelytrum repens (Willd.) C. E. Hubbard & 9 & 16 & 12.5 & 0.51 \\
\hline Panicum maximum Jacq. & 7 & 24 & 15.5 & 0.62 \\
\hline Leptochloa caerulescens Steud. & 160 & 167 & 163.5 & 6.86 \\
\hline Panicum repens Linn. & 14 & 23 & 18.5 & 0.76 \\
\hline Loudetia arundinacea (Hochst. ex. A. Rich.) & 182 & 167 & 174.5 & 7.25 \\
\hline Rottboellia cochinchinensis (Lour.) Clayton & 3 & 9 & 6 & 0.24 \\
\hline Digitaria horizontalis Willd & 9 & 27 & 18 & 0.72 \\
\hline
\end{tabular}

* The new weed 
Passiflora foetida was observed as the most dominant and frequent weed species, has the highest frequency of occurrence (16.99\%) followed by Tridax procumbens (12.20\%), Imperata cylindrica (11.51\%), Loudetia arundinacea (7.25\%), Euphorbia heterophylla (6.99\%), and Leptochloa caerulescens (6.86\%). The weeds with lowest frequencies were Mariscus alternifolius (0.22\%), Rottboellia cochinchinensis (0.24\%) and Synedrella nodiflora (0.29\%).

Table 2. The Occurrence of Passiflora. foetida L. and Associated Weed Species across Arable Fields During Vegetative Stage of Crops

\begin{tabular}{|c|c|c|c|c|c|c|c|c|c|}
\hline \multirow[b]{2}{*}{ Transect } & \multirow[b]{2}{*}{ X } & \multirow[b]{2}{*}{$\begin{array}{c}\text { No. of } \\
\text { quadrats }\end{array}$} & \multicolumn{3}{|c|}{ Density $\left(\mathrm{no} / \mathrm{m}^{2}\right)$} & \multicolumn{2}{|c|}{ Relative } & \multirow[b]{2}{*}{$\begin{array}{c}\text { Mean } \\
\text { density }\end{array}$} & \multirow{2}{*}{$\begin{array}{c}\text { Relative } \\
\text { Abundance } \\
(\%)\end{array}$} \\
\hline & & & $\begin{array}{c}P . \\
\text { foetida }\end{array}$ & $\begin{array}{l}\text { Associated } \\
\text { weed spp. }\end{array}$ & Total & Frequency & Density & & \\
\hline $\mathrm{A} 1$ & 6 & 16 & 35 & 150 & 185 & 0.38 & 0.189 & 2.188 & 28.20 \\
\hline $\mathrm{A} 2$ & 6 & 16 & 51 & 225 & 306 & 0.38 & 0.166 & 3.188 & 27.05 \\
\hline A3 & 8 & 16 & 40 & 285 & 325 & 0.50 & 0.123 & 2.500 & 31.15 \\
\hline A4 & 8 & 17 & 45 & 208 & 253 & 0.47 & 0.177 & 2.647 & 32.15 \\
\hline A5 & 10 & 16 & 50 & 249 & 299 & 0.63 & 0.167 & 3.125 & 39.60 \\
\hline A6 & 9 & 19 & 76 & 305 & 381 & 0.42 & 0.199 & 4.000 & 31.00 \\
\hline A7 & 11 & 21 & 55 & 215 & 270 & 0.52 & 0.203 & 2.619 & 36.34 \\
\hline A8 & 15 & 21 & 79 & 270 & 349 & 0.71 & 0.226 & 3.762 & 47.02 \\
\hline A9 & 12 & 20 & 95 & 250 & 345 & 0.60 & 0.275 & 4.750 & 43.07 \\
\hline A10 & 12 & 20 & 160 & 186 & 346 & 0.60 & 0.462 & 8.000 & 53.12 \\
\hline A11 & 11 & 20 & 76 & 181 & 257 & 0.55 & 0.295 & 3.950 & 42.28 \\
\hline A12 & 12 & 20 & 129 & 243 & 372 & 0.60 & 0.346 & 6.450 & 47.33 \\
\hline A13 & 13 & 20 & 115 & 244 & 359 & 0.65 & 0.320 & 5.750 & 48.51 \\
\hline A14 & 11 & 20 & 65 & 256 & 321 & 0.55 & 0.202 & 3.250 & 37.60 \\
\hline A15 & 11 & 20 & 81 & 242 & 323 & 0.55 & 0.250 & 4.050 & 40.03 \\
\hline A16 & 13 & 20 & 114 & 224 & 338 & 0.65 & 0.337 & 5.700 & 49.36 \\
\hline A17 & 13 & 20 & 106 & 208 & 314 & 0.65 & 0.337 & 5.300 & 49.37 \\
\hline A18 & 14 & 20 & 161 & 207 & 368 & 0.70 & 0.444 & 8.050 & 57.27 \\
\hline A19 & 13 & 20 & 127 & 231 & 358 & 0.65 & 0.354 & 6.350 & 50.27 \\
\hline A20 & 14 & 21 & 117 & 258 & 375 & 0.66 & 0.312 & 5.571 & 48.60 \\
\hline A21 & 13 & 20 & 81 & 300 & 381 & 0.65 & 0.212 & 4.050 & 43.12 \\
\hline A22 & 16 & 20 & 130 & 207 & 337 & 0.80 & 0.385 & 6.500 & 59.28 \\
\hline A23 & 14 & 20 & 90 & 235 & 325 & 0.70 & 0.276 & 4.500 & 48.84 \\
\hline A24 & 11 & 20 & 122 & 242 & 364 & 0.55 & 0.335 & 6.100 & 44.25 \\
\hline A25 & 13 & 20 & 127 & 252 & 379 & 0.65 & 0.335 & 6.350 & 49.25 \\
\hline A26 & 14 & 20 & 133 & 178 & 311 & 0.70 & 0.427 & 6.650 & 59.38 \\
\hline A27 & 14 & 20 & 138 & 200 & 338 & 0.70 & 0.408 & 6.900 & 55.40 \\
\hline A28 & 8 & 20 & 77 & 236 & 313 & 0.40 & 0.246 & 3.850 & 32.30 \\
\hline A29 & 11 & 20 & 117 & 226 & 343 & 0.55 & 0.516 & 5.850 & 53.30 \\
\hline A30 & 12 & 20 & 119 & 217 & 336 & 0.60 & 0.645 & 5.950 & 62.29 \\
\hline A31 & 12 & 20 & 73 & 177 & 250 & 0.60 & 0.292 & 3.650 & 44.60 \\
\hline A32 & 12 & 21 & 53 & 202 & 255 & 0.60 & 0.207 & 2.650 & 40.39 \\
\hline
\end{tabular}

$\mathrm{X}=$ number of quadrats that $P$. foetida occurred 
Passiflora foetida $L$ had a relative abundance ranging from 27.05 to $62.29 \%$ at the vegetative crop growth stage (Table 2) while at the harvesting stage of the crops, a relative abundance of $17.49 \%$ was the least recorded while the highest was $74.75 \%$.

Table 3. The Occurrence of Passiflora foetida $L$. and Associated Weed Species across Arable Fields During at Harvest.

\begin{tabular}{|c|c|c|c|c|c|c|c|c|c|}
\hline \multirow[b]{2}{*}{ Transect } & \multirow[b]{2}{*}{$X$} & \multirow[b]{2}{*}{$\begin{array}{l}\text { No. of } \\
\text { quadrats }\end{array}$} & \multicolumn{3}{|c|}{ Density $\left(\mathrm{no} / \mathrm{m}^{2}\right)$} & \multicolumn{2}{|c|}{ Relative } & \multirow[b]{2}{*}{$\begin{array}{c}\text { Mean } \\
\text { density }\end{array}$} & \multirow[b]{2}{*}{$\begin{array}{c}\text { Relative } \\
\text { Abundance } \\
\text { (\%) }\end{array}$} \\
\hline & & & $\begin{array}{c}P . \\
\text { foetida }\end{array}$ & $\begin{array}{l}\text { Associated } \\
\text { weed spp. }\end{array}$ & Total & Frequency & Density & & \\
\hline A1 & 5 & 16 & 11 & 279 & 290 & 0.31 & 0.038 & 0.688 & 17.49 \\
\hline A2 & 6 & 16 & 136 & 391 & 527 & 0.38 & 0.258 & 8.500 & 31.65 \\
\hline A3 & 7 & 16 & 29 & 389 & 418 & 0.44 & 0.069 & 1.813 & 25.31 \\
\hline A4 & 12 & 17 & 124 & 326 & 450 & 0.71 & 0.275 & 7.294 & 59.09 \\
\hline A5 & 9 & 16 & 77 & 240 & 317 & 0.56 & 0.242 & 4.813 & 40.24 \\
\hline A6 & 12 & 19 & 110 & 258 & 368 & 0.63 & 0.298 & 5.789 & 46.49 \\
\hline A7 & 10 & 21 & 96 & 254 & 350 & 0.48 & 0.274 & 4.571 & 37.50 \\
\hline A8 & 19 & 21 & 509 & 352 & 861 & 0.90 & 0.591 & 24.24 & 74.75 \\
\hline A9 & 17 & 20 & 177 & 339 & 516 & 0.81 & 0.340 & 8.850 & 57.60 \\
\hline A10 & 14 & 20 & 314 & 287 & 601 & 0.67 & 0.522 & 15.70 & 59.40 \\
\hline A11 & 14 & 20 & 130 & 348 & 478 & 0.70 & 0.271 & 6.500 & 48.59 \\
\hline A12 & 17 & 20 & 543 & 355 & 898 & 0.85 & 0.604 & 27.15 & 72.73 \\
\hline A13 & 16 & 20 & 308 & 362 & 670 & 0.80 & 0.459 & 15.40 & 62.98 \\
\hline A14 & 15 & 20 & 175 & 354 & 529 & 0.75 & 0.330 & 8.750 & 54.04 \\
\hline A15 & 14 & 20 & 109 & 369 & 478 & 0.70 & 0.228 & 5.450 & 46.40 \\
\hline A16 & 15 & 20 & 116 & 388 & 504 & 0.75 & 0.329 & 5.800 & 53.96 \\
\hline A17 & 17 & 20 & 443 & 304 & 747 & 0.85 & 0.593 & 22.15 & 72.15 \\
\hline A18 & 14 & 20 & 270 & 401 & 671 & 0.70 & 0.402 & 13.50 & 55.10 \\
\hline A19 & 13 & 20 & 215 & 445 & 660 & 0.68 & 0.325 & 10.75 & 50.48 \\
\hline A20 & 16 & 21 & 288 & 380 & 668 & 0.80 & 0.431 & 13.71 & 61.55 \\
\hline A21 & 18 & 20 & 243 & 406 & 649 & 0.90 & 0.374 & 12.15 & 63.72 \\
\hline A22 & 17 & 20 & 275 & 375 & 650 & 0.85 & 0.423 & 13.75 & 63.65 \\
\hline A23 & 18 & 20 & 277 & 354 & 631 & 0.90 & 0.438 & 13.85 & 66.94 \\
\hline A24 & 14 & 20 & 173 & 376 & 549 & 0.70 & 0.315 & 8.650 & 50.75 \\
\hline A25 & 16 & 20 & 165 & 304 & 469 & 0.80 & 0.351 & 8.250 & 57.59 \\
\hline A26 & 18 & 20 & 111 & 306 & 417 & 0.90 & 0.266 & 5.550 & 58.30 \\
\hline A27 & 18 & 20 & 301 & 283 & 584 & 0.90 & 0.515 & 15.05 & 70.77 \\
\hline A28 & 15 & 20 & 199 & 271 & 470 & 0.75 & 0.423 & 9.900 & 58.65 \\
\hline A29 & 16 & 20 & 162 & 332 & 494 & 0.80 & 0.327 & 8.100 & 56.39 \\
\hline A30 & 17 & 20 & 179 & 293 & 472 & 0.85 & 0.379 & 8.950 & 61.46 \\
\hline A31 & 16 & 20 & 121 & 304 & 425 & 0.80 & 0.284 & 6.050 & 54.23 \\
\hline A32 & 15 & 21 & 76 & 323 & 399 & 0.71 & 0.190 & 3.800 & 45.02 \\
\hline
\end{tabular}

$X=$ number of quadrats that $P$. foetida occurred. 
(Table 3) indicating a highly infested agricultural arable fields. This is in agreement with the report of Takim (2012) who stated that Euphorbia heterophylla, Passiflora foetida and Cleome viscosa were more in abundance in the continuously cultivated maize fields at Ballah.

Table 4. Frequency of Occurrence (\%) of $P$. foetida $L$. at Vegetative and Harvest Stage in Different Cropping Systems.

\begin{tabular}{lcc}
\hline Cropping system & Vegetative & Harvest \\
\hline Fallow field & $\%$ & 3.53 \\
Sole Cassava & 3.05 & 3.16 \\
Sole Cowpea & 6.96 & 40.50 \\
Sole Maize & 28.93 & 3.81 \\
Sole Soyabean & 4.27 & 36.34 \\
Cassava/Maize intercrop & 38.56 & 12.1 \\
Cassava / Yam intercrop & 15.98 & 0.46 \\
Cassava/ Maize /Yam intercrop & 0.60 & 0 \\
\hline
\end{tabular}

The frequency of occurrence of the new weed species differed across different cropping systems (Table 4). The fields of cowpea and soyabean had higher frequencies of occurrence compare with sole cassava and maize plots with lower frequencies of occurrence. This supports the report of Lemerle \& Murphy, (2000) that broadleaf weeds tend to increase in continuous broadleaf crops such as legume crop while Blackshaw (1994) observed that cereal crops grown continuously for several years tend to select for grass weeds. Weeds adaptation to cropping system could be due to a consistently hospitable environment for weeds that have phenological and physiological similarities to the crop (Murphy \& Lemerle, 2006).

The intercrop fields had a relatively lower incidence of the new weed except cassava/maize intercrop plot that had higher frequency of occurrence than sole maize and sole cassava plots. Cassava/yam or cassava/maize/yam intercrops had the least frequency of occurrence ranging from 0 to $1.69 \%$. The shading effect resulting from the crop canopy limit availability of resources required for weed germination. This effect is more pronounced in intercrops because of the combined foliage of the component crops which intercepted most of the green and red light leaving far red to reach the ground. Far red light is known to be inhibitory to weed germination (Clark \& Francis, 1985) could be responsible for the better weed (P. foetida) suppression by the intercropped fields. The reduction in weed densities of intercropped fields could also be as a result 
of limited availability of resources to weed species. The interrow spaces provide room for weeds to flourish in monocrops compared to the intercrops, therefore increasing weed density in monocrops.

\section{CONCLUSION}

Passiflora foetida was found to have the highest frequency of occurrence (16.99\%) and relative abundance ranging from 27.05 to $62.29 \%$ and 17.49 to $74.75 \%$ at vegetative and harvesting stage of crop life, respectively. The new weed dominated the cowpea and soyabean monoculture fields compared to plots with sole cassava, sole maize, and their intercrops. This study recommends periodical observation of weed flora by farmers to ascertain cases of invasion of farmlands by alien weed species this would enable early adoption of an effective management strategy that could limit its spread.

\section{REFERENCES}

Akobundo I.O. and Agyakwa C.W. (1998). "A Hand book of West African Weeds". IITA, IbadanNigeria. 521pp.

Beninca, J.P., Montanher, A.B., Zucolotto, S.M., Schen-kel, E.P., Frode, T.S. (2007). "Evaluation of the anti-inflammatory efficacy of Passiflora edulis". Food Chemistry, 104: 10971105.

Blackshaw, R.E. (1994). "Rotation affects downy brome (Bromus tectorum) in winter wheat (Triticum aestivum)". Weed Technology 8: 728 - 732.

Chopra, R.N., Nayar, S.L., Chopra, I.C. (1956). Glossary of Indian Medicinal Plants. CSIR: New Delhi.

Clark, E. A. and Francis, C. A. (1985). "Transgressive yielding in maize-bean intercrops: Interference in space and time". Field Crops Research 11: 37-53.

Dhawan, K., Kumar, S., Sharma, A.(2001). "Anti-anxiety studies on extracts of Passiflora incarnata Linneaus". Journal of Ethno-pharmacology 78 (2-3): 165-170.

Dhawan, K., Dhawan, S., Sharma, A. (2004). "Passiflora: a review update", Journal of Ethnopharmacology 94: 123.

Gurbachan, S. (2005). Weed management for sustainable agriculture. Proceeding of National Biennial Conference of Indian Society of Weed Science, pp. 1-6.

Kamal-Uddin, M.D., Juraimi, A.S., Begum, M., Ismail, M.R., Abdul Rahim, A. and Othman, R. (2009). "Floristic Composition of Weed Community in Turf Grass Area of West Peninsular Malaysia". International Journal of Agriculture \& Biology 11(1):13-20

Kinghorn, G.R. (2001)." Passion, stigma and STI". Sex Transm Inf. 77: 370 - 375.

Lemerle, D. and Murphy, C.E. ( 2000). "Cultural management methods". In: B.M. Sindel (Ed.), Australian Weed Management Systems, pp. 123-138 
Mack, R. N., Simberloff, D., Lonsdale, W. M., Evans, H., Clout, M. and Bazzaz, F. A. ( 2000). "Biotic invasions: causes, epidemiology, global consequences, and control". Ecological Application 10:689-710.

Montanher, A.B., Zucolotto, S.M., Schenkel, E.P., Frode, T.S. (2007). "Evidence of antiinflammatory effects of Passif-lora edulis in an inflammation model", Journal of Ethnopharmacology 109: 281 - 288.

Moore, A.W. and McMakin, R.T. (2002). Global invasive weed species database, retrieved from http: org Database Ecology of Passiflora foetida.

Murphy, C.E and Lemerle, D. (2006). "Continuous cropping systems and weed selection". Euphytica 148: 61- 73

Murugan, G. and Kathiresan, R. M. (2010). "Ecological Studies on Weeds of Sugarcane Fields". Plant Archives 10 (2): 667-669.

Pacific Island Ecosystem at Risk "PIER" (2002). Description of Passiflora foetida, retrieved from http:org Database of Ecology of Passiflora foetida.

Pimentel, D., Zuniga, R. and Morrison, D. (2005). "Update on the environmental and economic costs associated with alien-invasive species in the United States". Ecological Economic. $52: 273-288$.

Randall. R.,(2003). Global invasive weed species database, retrieved from http: org Database Ecology of Passiflora foetida.

Stohlgren, T. J., Barnett, D. T., Jarnevich, C. S., Flather, C. and Kartesz, J. ( 2008). "The myth of plant species saturation". Ecological Letter 11:313-326.

Takim, F.O.(2012). Influence of cropping system, land use intensity and weed management practice on seedbank and floristic composition of weeds. A Ph.D Thesis, University of Ilorin, Nigeria. Pg 227.

Takim, F.O. and Fadayomi, O. (2010). "Influence of Tillage and Cropping Systems on Field Emergence and Growth of Weeds and Yield of Maize (Zea mays L.) and Cowpea (Vigna unguiculata L.)". Australian Journal of Agricultural Engineering 1(4):141-148.

The Wealth of India (2001). "A Dictionary of Indian Raw Materials and Industrial Products", CSIR, 7:278-79.

Thomas, A.G., (1985). "Weed survey system used in Saskatchewan for cereal and oilseed crops". Weed Science, 33: 34 - 43

Wilcove, D. S., Rothstein, D., Dubow, J., Phillips, A. and Losos, E. (1998). "Quantifying threats to imperiled species in the United States". Bioscience 48:607 -615. 